Ms. For Organometallics (for the special issue dedicated to Professor Ernesto Carmona)

Ms. ID.: om-2017-00905v.R1 (revised manuscript)

\title{
Ruthenium Carbene Complexes Analogous to Grubbs-I Catalysts Featuring Germylenes as Ancillary Ligands
}

Lucía Álvarez-Rodríguez, ${ }^{a}$ Javier A. Cabeza, ${ }^{*, a}$ Pablo García-Álvarez,*,a and

Enrique Pérez-Carreño ${ }^{b}$

aCentro de Innovación en Química Avanzada (ORFEO-CINQA), Departamento de Química Orgánica e Inorgánica, Universidad de Oviedo, 33071 Oviedo, Spain

'Departamento de Química Física y Analítica, Universidad de Oviedo, 33071 Oviedo, Spain

*E-mail: jac@uniovi.es (J.A.C.) and pga@uniovi.es (P.G.-A.) 
ABSTRACT: Reactions of the first-generation Grubbs' catalyst trans- $\left[\mathrm{RuCl}_{2}(\mathrm{CHPh})(\mathrm{PCy})_{2}\right](\mathbf{1})$ with the amidinatogermylenes $\mathrm{Ge}\left({ }^{t} \mathrm{Bu}_{2}\right.$ bzam $) \mathrm{R}\left(\mathrm{R}={ }^{t} \mathrm{Bu}\left(\mathbf{L}^{1}\right), \mathrm{CH}_{2} \mathrm{SiMe}_{3}\left(\mathbf{L}^{2}\right) ;{ }^{t} \mathrm{Bu}_{2}\right.$ bzam $=N, N^{\prime}-$ bis(tertbutyl)benzamidinate) have allowed the isolation and full characterization of the first specimens of Grubbs-type carbene complexes featuring heavier tetrylenes as ancillary ligands, namely, the disubstituted derivatives trans-[RuCl$\left.{ }_{2}(\mathrm{CHPh})\left(\mathbf{L}^{\mathbf{1}}\right)_{2}\right](\mathbf{3})$ and cis-[RuCl$\left(\mathrm{CHPh}_{2}\left(\mathbf{L}^{2}\right)_{2}\right]$ (7), which, curiously, differ in the arrangement of their germylene ligands. DFT calculations have revealed that the different volume of $\mathbf{L}^{1}$ and $\mathbf{L}^{2}$ (the former is larger than the latter) is responsible for the different stereochemistry of $\mathbf{3}$ and 7. NMR-monitoring of the reaction solutions has allowed the observation of the monosubstituted intermediates trans- $\left[\mathrm{RuCl}_{2}(\mathrm{CHPh})(\mathrm{L})(\mathrm{PCy})\right](\mathrm{L}=$ $\mathbf{L}^{1}$ (2), $\mathbf{L}^{2}(\mathbf{5})$ ) and their evolution to either the disubstituted final product (for $\mathbf{L}^{\mathbf{1}}$ ) trans$\left[\mathrm{RuCl}_{2}(\mathrm{CHPh})\left(\mathbf{L}^{1}\right)_{2}\right]$ (3) or to the short-lived disubstituted intermediate (for $\mathbf{L}^{2}$ ) trans$\left[\mathrm{RuCl}_{2}(\mathrm{CHPh})\left(\mathbf{L}^{2}\right)_{2}\right](\mathbf{6})$. Complex 7 arises from a trans-to-cis isomerization of intermediate 6. As olefin metathesis catalysts, both 3 and 7 promoted the ring-closing metathesis of diethyl 2,2diallylmalonate and the ring-opening metathesis polymerization of norbornene, but their catalytic activity decreased with the reaction time, indicating catalyst decomposition.

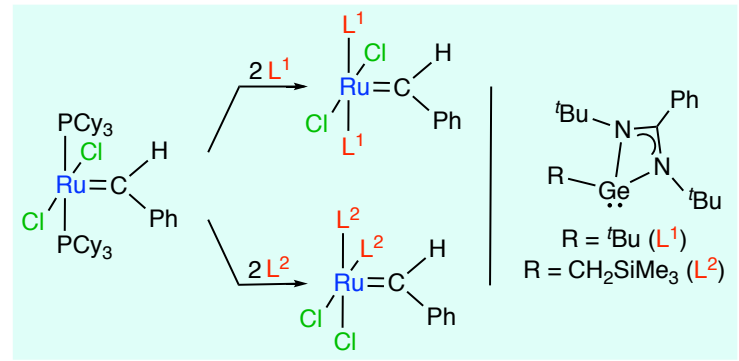




\section{INTRODUCTION}

The appearance in the early nineties of the olefin metathesis-active ruthenium alkylidene complexes $\left[\mathrm{RuCl}_{2}(\mathrm{CHPh})\left(\mathrm{PR}_{3}\right)_{2}\right]$, known as Grubbs' first-generation catalysts (Grubbs-I, Figure 1) ${ }^{1}$ boosted the use of this catalytic reaction in organic synthesis and polymer chemistry. ${ }^{2}$ The stability and catalytic activity of these catalysts were greatly improved by Grubbs' secondgeneration catalysts, $\left[\mathrm{RuCl}_{2}(\mathrm{CHPh})(\mathrm{NHC})\left(\mathrm{PR}_{3}\right)\right]$ (Grubbs-II, Figure 1), that arise from the replacement of one phosphane ligand by an N-heterocyclic carbene (NHC). ${ }^{3}$ This improvement was attributed to the stronger electron-donor capacity and higher steric bulk of NHC ligands, which, in addition to decrease the rate of catalyst decomposition, since (bulky) NHCs are more tightly bound to the metal atom and provide a greater steric protection than phosphane ligands, they enhance the affinity of coordinatively unsaturated ruthenium intermediate species for $\pi$ accepting alkene substrates. ${ }^{4}$

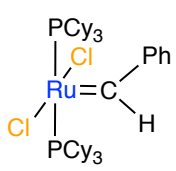

(Grubbs-I)

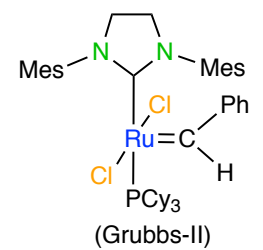

Figure 1. Representative examples of Grubbs' first-generation (left) and second-generation (right) catalysts for olefin metathesis.

On the other hand, recent reports have demonstrated that some heavier tetrylenes (heavier carbene analogues), in particular, donor-stabilized silylenes and germylenes (derived from amidinato, $\beta$-diketiminato, and other chelating fragments) are very strong electron-donating ligands,${ }^{5,6}$ even stronger than most phosphanes and many NHCs. ${ }^{6}$

Having in mind the aspects exposed in the above paragraphs, we decided to investigate the synthesis of ruthenium(II) alkylidene complexes that, being related to Grubbs-type metathesis catalysts, have strongly donating heavier tetrylenes instead of phosphanes and/or NHCs as ancillary ligands. In addition of being an interesting synthetic challenge, these unprecedented complexes, relying on the many different steric and electronic profiles provided by heavier tetrylene ligands, could open new opportunities not only in synthetic organometallic chemistry but also in the field of olefin metathesis. As far as we are aware, the preparation of complexes of such 
a type has been (admittedly) attempted only once: Hill and co-workers reacted trans$\left[\mathrm{RuCl}_{2}(\mathrm{CHPh})\left(\mathrm{PCy}_{3}\right)_{2}\right](\mathbf{1})$ with the non-donor-stabilized silylene 1,3-bis(tertbutyl)-2-silaimidazol2-ylidene, $\mathrm{Si}\left(\mathrm{N}^{t} \mathrm{Bu}\right)_{2} \mathrm{C}_{2} \mathrm{H}_{2}$, but they isolated the alkylidene substitution product trans$\left[\mathrm{RuHCl}\left\{\mathrm{Si}\left(\mathrm{N}^{t} \mathrm{Bu}\right)_{2} \mathrm{C}_{2} \mathrm{H}_{2}\right\}\left(\mathrm{PCy}_{3}\right)_{2}\right]$ instead of a phosphane substitution derivative. ${ }^{7}$

We now report that both phosphane ligands of the Grubbs-I catalyst $\mathbf{1}$ can be satisfactorily replaced by the very basic and bulky amidinatogermylenes $\operatorname{Ge}\left({ }^{t} \mathrm{Bu}_{2}\right.$ bzam $) \mathrm{R}\left({ }^{t} \mathrm{Bu}_{2}\right.$ bzam $=\mathrm{N}, \mathrm{N}$ 'bis(tertbutyl)benzamidinate; $\left.\mathrm{R}={ }^{t} \mathrm{Bu}\left(\mathbf{L}^{1}\right), \mathrm{CH}_{2} \mathrm{SiMe}_{3}\left(\mathbf{L}^{2}\right)\right)$ and that $\mathrm{X}$-ray diffraction studies have shown that the arrangement of the germylene ligands in the final square-pyramidal disubstituted products depends upon the germylene $\mathrm{R}$ group, being trans for $\mathrm{R}={ }^{t} \mathrm{Bu}$ (complex 3 ) but cis for $\mathrm{R}=$ $\mathrm{CH}_{2} \mathrm{SiMe}_{3}$ (complex 7). NMR-monitoring of the reactions has allowed the observation of monosubstituted intermediates. The disubstituted complexes have shown a low catalytic activity in the ring-closing metathesis of diethyl 2,2-diallylmalonate to diethyl cyclopent-3-ene-1,1dicarboxylate and the ring-opening metathesis polymerization of norbornene.

\section{RESULTS AND DISCUSSION}

The room temperature reaction of $\mathbf{1}$ with one equivalent of $\mathrm{Ge}\left({ }^{t} \mathrm{Bu}{ }_{2} \mathrm{bzam}\right)^{t} \mathrm{Bu}\left(\mathbf{L}^{1}\right)$ led to a mixture of products (vide infra) that could not be separated. However, the use of an excess of the germylene ( $\mathbf{1}: \mathbf{L}^{1}$ mole ratio $=1: 2.3$ ) led to a single reaction product, the disubstituted derivative trans-[RuCl$\left.{ }_{2}(\mathrm{CHPh})\left(\mathbf{L}^{1}\right)_{2}\right](\mathbf{3}$; Scheme 1), which was isolated in high yield $(82 \%)$ and could be fully characterized.

\section{Scheme 1. Equilibria between Products Arising from Complex 1 and Germylene $\mathbf{L}^{1}$}

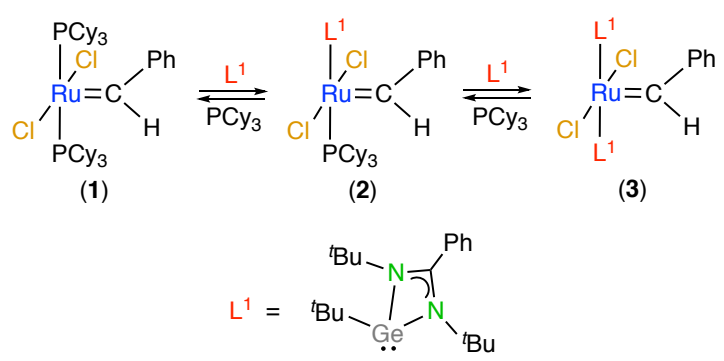

The X-ray diffraction (XRD) molecular structure of complex 3 is shown in Figure 2. The metal atom is in a distorted square pyramidal ligand arrangement, with the benzylidene moiety occupying the apical position and the chlorido and germylene ligands at the basal corners in a 
mutual trans disposition. The ruthenium atom is 0.212(1) $\AA$ away from the basal plane, shifted toward the benzylidene group. All the geometrical parameters of $\mathbf{3}$ are close to those previously reported for related trans- $\left[\mathrm{RuCl}_{2}(\mathrm{CHPh})(\mathrm{L})_{2}\right]\left(\mathrm{L}=\text { phosphane or } \mathrm{NHC}^{8}\right)^{9}$ complexes. ${ }^{1 \mathrm{a}, 1 \mathrm{~b}, 10}$ The $\mathrm{Ru}-$ $\mathrm{C}_{\text {carbene }}$ bond distance, 1.845(7) $\AA$, is in the top limit of the range of $\mathrm{Ru}-\mathrm{C}$ distances reported for related complexes, 1.818(4) to $1.845(2),{ }^{1 \mathrm{a}, 1 \mathrm{~b}, 10}$ being slightly longer than that of $\mathbf{1}$ (1.841(2) $\AA$ )..$^{10 \mathrm{c}}$ The benzylidene group is disposed approximately perpendicular to the $\mathrm{Ge}-\mathrm{Ru}-\mathrm{Ge}$ plane, with the aryl ring plane forming and angle $27.5(2)^{\circ}$ of with the $\mathrm{Cl} 1-\mathrm{Ru}-\mathrm{Cl} 2-\mathrm{C} 20$ plane. Due to the large volume of germylene $\mathbf{L}^{1}$, the $\mathrm{Ru}-\mathrm{Ge}$ distances of $\mathbf{3}, 2.4575(9) \AA$ and 2.5043(9) $\AA$, are longer than those of the few ruthenium complexes equipped with germylenes as terminal ligands that have hitherto been characterized by XRD, which are in the range 2.2821(6) to 2.4363(7) $\AA .{ }^{11}$

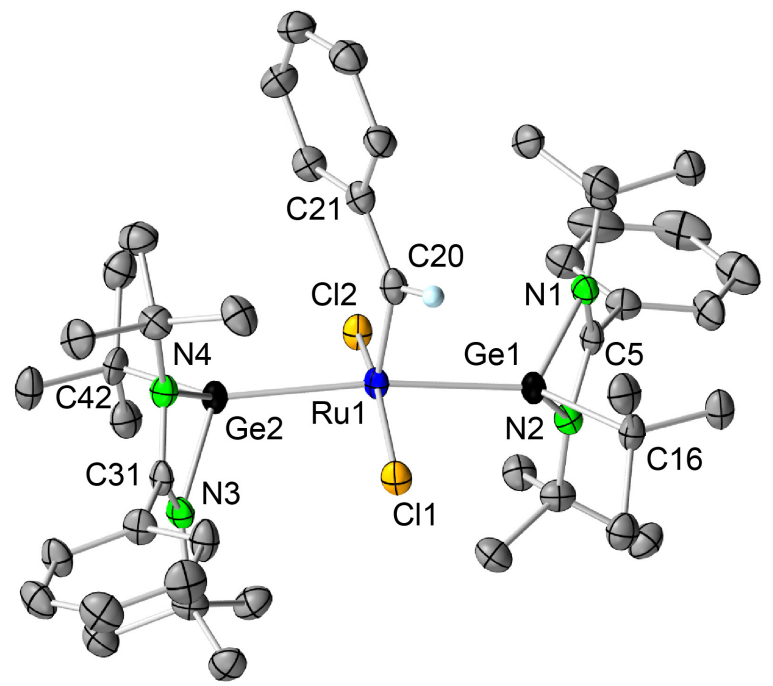

Figure 2. Molecular structure of complex 3 (30\% displacement ellipsoids, $\mathrm{H}$ atoms have been omitted for clarity except that on C20). Selected bond lengths ( $\AA$ ) and angles ( $\left.{ }^{\circ}\right)$ : Ru1-C20 1.845(7), Ru1-Cl1 2.408(2), Ru1-Cl2 2.392(2), Ru1-Ge1 2.4575(9), Ru1-Ge2 2.5043(9), C5-N1 1.339(9), C5-N2 1.331(8), C16-Ge1 2.014(7), C20-C21 1.45(1), C31-N3 1.326(9), C31-N4 1.333(9), C42-Ge2 2.024(7), Ge1-N1 1.976(5), Ge1-N2 1.977(6), Ge2-N3 1.984(5), Ge2-N4 1.971(6), C20-Ru1-Cl1 90.8(2), C20-Ru1-Cl2 107.1(2), C20-Ru1-Ge1 89.2(2), C20-Ru1-Ge2 99.3(2), Cl1-Ru1-Ge1 90.06(5), Cl1-Ru1-Ge2 89.91(5), Cl2-Ru1-Cl1 161.88(6), Cl2-Ru1-Ge1 87.46(5), Cl2-Ru1-Ge2 89.94(5), Ge1-Ru1-Ge2 171.55(3).

The NMR spectra of $\mathbf{3}$ are very simple. The resonances of the benzylidene $\mathrm{Ru}=\mathrm{CH}$ group appear at very high chemical shifts in both the ${ }^{1} \mathrm{H}$ and ${ }^{13} \mathrm{C}\left\{{ }^{1} \mathrm{H}\right\}$ spectra, $20.43 \mathrm{ppm}$ and $290.0 \mathrm{ppm}$, respectively, in $\mathrm{C}_{6} \mathrm{D}_{6}$. For comparison, those of complex 1 were observed at $20.02 \mathrm{ppm}$ and 294.7 ppm, respectively, in $\mathrm{CD}_{2} \mathrm{Cl}_{2}{ }^{1 \mathrm{a}, \mathrm{lb}}$ Regarding the germylene ligands, both are equivalent in the ${ }^{1} \mathrm{H}$ and ${ }^{13} \mathrm{C}\left\{{ }^{1} \mathrm{H}\right\}$ spectra, each spectrum showing singlets for the $\mathrm{Ge}^{t} \mathrm{Bu}$ and $\mathrm{N}^{\prime} \mathrm{Bu}$ methyl groups. 
Aiming at gathering more information on the formation of complex $\mathbf{3}$, the outcomes of reactions of complex 1 with different amounts of $\mathbf{L}^{\mathbf{1}}$ in $\mathrm{C}_{6} \mathrm{D}_{6}$ at room temperature were studied by ${ }^{1} \mathrm{H}$ and ${ }^{31} \mathrm{P}\left\{{ }^{1} \mathrm{H}\right\}$ NMR (Figure 3). After $1 \mathrm{~h}$, the ${ }^{1} \mathrm{H}$ spectrum of a 1:1 reaction (Figure 3a) showed three signals assignable to the benzylidene $\mathrm{Ru}=\mathrm{CH}$ proton of unreacted $\mathbf{1}(20.59 \mathrm{ppm}), \mathbf{3}(20.43$ $\mathrm{ppm})$ and a third and major $(67 \%)$ product $(2 ; 20.36 \mathrm{ppm})$. The corresponding ${ }^{31} \mathrm{P}\left\{{ }^{1} \mathrm{H}\right\} \mathrm{NMR}$ spectrum indicated the presence of $1(36.3 \mathrm{ppm})$, free $\mathrm{PCy}_{3}(10.0 \mathrm{ppm})$ and another product (2; $34.9 \mathrm{ppm}$ ). These spectra (recorded $1 \mathrm{~h}$ after mixing the reagents) were identical to those recorded after 18 h. Complex 2 could not be separated as a pure product from this reaction mixture.

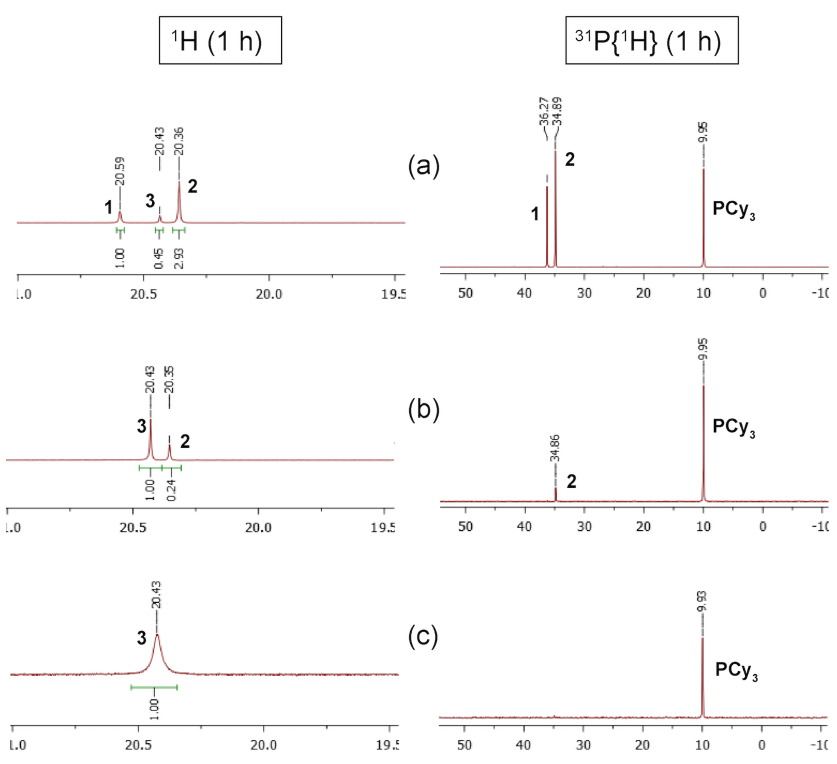

Figure 3. ${ }^{1} \mathrm{H}$ (left, $400.1 \mathrm{MHz}, \mathrm{Ru}=\mathrm{CH}$ region only) and ${ }^{31} \mathrm{P}\left\{{ }^{1} \mathrm{H}\right\}$ (right, $162.1 \mathrm{MHz}$ ) NMR spectra $(293 \mathrm{~K})$ of samples obtained (a) after mixing $\mathbf{1}$ with one equiv. of $\mathbf{L}^{1}$ in $\mathrm{C}_{6} \mathrm{D}_{6}$ and stirring for $1 \mathrm{~h}$, (b) after adding one equiv. of $\mathbf{L}^{1}$ to the previous solution and stirring for $1 \mathrm{~h}$, and (c) after adding half equiv. of $\mathbf{L}^{1}$ to the previous solution and stirring for $1 \mathrm{~h}$. Chemical shifts $(\delta)$ are given in ppm.

The addition of more $\mathbf{L}^{1}$ to the previous reaction mixture allowed us to infer the nature of intermediate $2.1 \mathrm{~h}$ after adding one further equiv. of $\mathbf{L}^{\mathbf{1}}$ (Figure $3 \mathrm{~b}$ ), beside indicating the total consumption of $\mathbf{1}$, the ${ }^{1} \mathrm{H}$ NMR spectrum showed the presence of $\mathbf{2}$ and $\mathbf{3}$ in a ca. 1:4 mole ratio, while the ${ }^{31} \mathrm{P}\left\{{ }^{1} \mathrm{H}\right\}$ NMR spectrum showed only free $\mathrm{PCy}_{3}$ and a small amount of 2 . No changes were observed $18 \mathrm{~h}$ after the addition of the second equiv. of germylene $\mathbf{L}^{\mathbf{1}}$. Further addition of 0.5 equiv. of $\mathbf{L}^{\mathbf{1}}$ (2.5 equiv. in total) led to $\mathbf{3}$ as the only benzylidene-containing product (Figure $3 \mathrm{c}$ ). The initial formation and subsequent disappearance of $\mathbf{2}$ in the synthesis of complex $\mathbf{3}$ from $\mathbf{1}$ and $\mathbf{L}^{1}$ led us to propose that complex $\mathbf{2}$ is the mixed germylene-phosphane derivative trans- 
$\left[\mathrm{RuCl}_{2}(\mathrm{CHPh})\left(\mathbf{L}^{1}\right)\left(\mathrm{PCy}_{3}\right)\right]$ (Scheme 1). This initial proposal was later corroborated by carefully studying the ${ }^{1} \mathrm{H}$ spectrum of the reaction mixture resulting from the addition of one equiv. of $\mathbf{L}^{1}$ to a $\mathrm{C}_{6} \mathrm{D}_{6}$ solution of complex $\mathbf{1}$, since the major component of the mixture (2) clearly showed the signals corresponding to a coordinated germylene (at different $\delta$ from those of 3 ) and a singlet corresponding to the benzylidene $\mathrm{Ru}=\mathrm{CH}$ proton $(20.36 \mathrm{ppm})$ (the signals of the benzylidene phenyl group and the coordinated $\mathrm{PCy}_{3}$ ligand were overlapped with those of other products). In addition, the chemical shift of the benzylidene $\mathrm{Ru}=\mathrm{CH}$ proton $(20.36 \mathrm{ppm})$ is within the range ( $c a$. 19-21 ppm) previously reported for complexes of the type trans- $\left[\operatorname{RuCl}_{2}(\mathrm{CHAr})(\mathrm{L})\left(\mathrm{L}^{\prime}\right)\right](\mathrm{L}=$ phosphane or NHC, with $\mathrm{L}^{\prime}=\mathrm{L}^{1 \mathrm{a}, 1 \mathrm{~b}, 10}$ or $\left.\mathrm{L}^{\prime} \neq \mathrm{L}^{4,10 \mathrm{f}, 12}\right)$, ruling out a cis arrangement of the ancillary ligands, since the benzylidene $\mathrm{Ru}=\mathrm{CH}$ proton of related cis complexes is observed at higher field (ca. 15-17 ppm) ${ }^{10 \mathrm{i}, \mathrm{f}, 12 \mathrm{a}, 13,14}$ Furthermore, it can be proposed that the $\mathrm{C}_{\text {carbene }}-\mathrm{H}$ bond of 2, similarly to those of $\mathbf{1}$ and $\mathbf{3}$, should lie roughly perpendicular to the Ge-Ru-P plane, since its $\mathrm{Ru}=\mathrm{CH}$ proton resonance is not coupled to ${ }^{31} \mathrm{P}^{1}{ }^{1,15}$ Such an observation has also been reported for related mixed NHC-phosphane derivatives featuring benzylidene groups approximately perpendicular to the NHC-Ru-P plane. .,10f, $12^{4}$

Therefore, the above-described data strongly support the reaction equilibria depicted in Scheme 1, in which the first $\mathrm{PCy}_{3}$ substitution (formation of $\mathbf{2}$ from $\mathbf{1}$ and $\mathbf{L}^{1}$ ) should occur at a similar rate than the subsequent $\mathrm{PCy}_{3}$ displacement (formation of $\mathbf{3}$ from $\mathbf{2}$ and $\mathbf{L}^{\mathbf{1}}$ ), without the participation of cis reaction products, such as cis-[ $\left.\mathrm{RuCl}_{2}(\mathrm{CHPh})\left(\mathbf{L}^{1}\right)\left(\mathrm{PCy}_{3}\right)\right]$ or cis$\left[\mathrm{RuCl}_{2}(\mathrm{CHPh})\left(\mathbf{L}^{1}\right)_{2}\right](\mathbf{4})$. Related results have been reported for reactions of complex $\mathbf{1}$ with some NHCs, such as 1,3-di(R)imidazol-2-ylidene $\left[\mathrm{R}={ }^{i} \mathrm{Pr}, \mathrm{Cy}, \mathrm{CHMePh}, \mathrm{CHMe}\left(1-\right.\right.$ naphthyl) ${ }^{10 \mathrm{k}}$ or 1(2,6-diisopropylphenyl)-3-(R)imidazolidin-2-ylidene $(\mathrm{R}=\mathrm{Me}, \mathrm{Cy}),{ }^{10 \mathrm{e}}$ which have allowed the preparation of bis(NHC) complexes but, in many instances, not of pure monosubstituted derivatives. However, for other NHCs, such as 1,3-dimesitylimidazolidin-2-ylidene ${ }^{10 g}$ or 1,3-

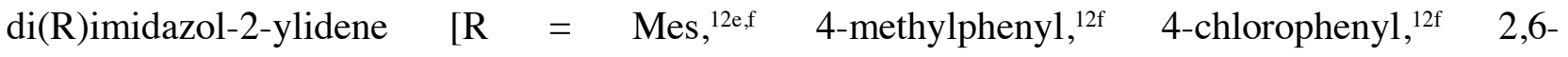
diisopropylpheny $\left.1^{12 c}\right)$, the phosphane exchange rate after the first $\mathrm{PCy}_{3}$ substitution suffers such a dramatic decrease ${ }^{10 \mathrm{~g}, 4}$ that only the mixed NHC-phosphane complexes can be prepared, even in the presence of a large excess of NHC. For these cases, the bis(NHC) benzylidene derivatives are accessible using more labile metal precursors, such as $\left[\mathrm{RuCl}_{2}(\mathrm{CHPh})\left(\mathrm{PPh}_{3}\right)_{2}\right]^{10 \mathrm{~d}}$ or $\left[\mathrm{RuCl}_{2}(\mathrm{CHPh})(\mathrm{NHC})(\mathrm{py})_{2}\right](\mathrm{py}=$ pyridine $) .^{10 \mathrm{~b}, \mathrm{~g}, \mathrm{~h}}$ 
Inspired by a report that describes that the bis(NHC) complex trans-[ $\left.\mathrm{RuCl}_{2}(\mathrm{CHPh})(\mathrm{SIMes})_{2}\right]$ (SIMes = 1,3-dimesitylimidazolidin-2-ylidene) reacts with $\mathbf{1}$ at $70{ }^{\circ} \mathrm{C}$ to form the mixed NHCphosphane complex trans-[RuCl$\left.{ }_{2}(\mathrm{CHPh})(\mathrm{SIMes})\left(\mathrm{PCy}_{3}\right)\right],{ }^{10 \mathrm{~g}}$ we carried out a 1:1 reaction of 1 with $\mathbf{3}$ aiming at a cleaner formation of complex $\mathbf{2}$. However, while $\mathbf{2}$ was immediately formed, even at room temperature, the presence of significant amounts of unreacted $\mathbf{1}$ and $\mathbf{3}$ (Figure S4) hampered an effective purification of $\mathbf{2}$. In addition, all attempts to isolate complex $\mathbf{2}$ from reactions of $\mathbf{L}^{\mathbf{1}}$ with the more labile precursors $\left[\mathrm{RuCl}_{2}(\mathrm{CHPh})\left(\mathrm{PCy}_{3}\right)(\mathrm{py})_{\mathrm{n}}\right](\mathrm{n}=1,2)^{16}$ were also unsuccessful. Our interest in preparing complex $\mathbf{2}$ was based in the assumption that it should be more active than complex $\mathbf{3}$ as catalyst for olefin metathesis, since bis(NHC) ruthenium alkylidene catalysts generally show lower catalytic activity than mixed NHC-phosphane complexes ${ }^{3}$ because, to form the catalytically-active 14-electron intermediate (by the accepted dissociative pathway ${ }^{4}$ ), NHC dissociation is more difficult than phosphane dissociation.

Having in mind that the formation of bis(NHC) complexes from complex $\mathbf{1}$ has been shown to depend on both the steric and the electronic properties of the NHC, ${ }^{10 g, 17}$ we decided to examine the reactivity of $\mathbf{1}$ with germylenes featuring steric and electronic profiles different from those of $\mathbf{L}^{\mathbf{1}}$, such as $\mathrm{Ge}\left({ }^{t} \mathrm{Bu}_{2}\right.$ bzam $) \mathrm{Cl}$ and $\mathrm{Ge}\left({ }^{t} \mathrm{Bu}_{2}\right.$ bzam $) \mathrm{CH}_{2} \mathrm{SiMe}_{3}\left(\mathbf{L}^{2}\right)$. While the chloridogermylene was unable to react with complex $1\left(18 \mathrm{~h}\right.$ at $\left.60{ }^{\circ} \mathrm{C}\right)$, presumably because of its low basicity, the novel germylene $\mathbf{L}^{2}$, which was prepared by treating $\mathrm{Ge}\left({ }^{t} \mathrm{Bu}_{2}\right.$ bzam $) \mathrm{Cl}$ with $\mathrm{LiCH}_{2} \mathrm{SiMe}_{3}$, resulted basic enough as to displace the $\mathrm{PCy}_{3}$ ligands of $\mathbf{1}$ at room temperature. However, as occurred with $\mathbf{L}^{\mathbf{1}}$, the isolation of a pure compound was only achieved when an excess of $\mathbf{L}^{2}\left(\mathbf{1}: \mathbf{L}^{2}\right.$ mole ratio = 1:2.3) was used. The final product, which was isolated in $89 \%$ yield, was subsequently identified as the cis-disubstituted derivative $c i s-\left[\mathrm{RuCl}_{2}(\mathrm{CHPh})\left(\mathbf{L}^{2}\right)_{2}\right](7 ;$ Scheme 2).

Scheme 2. Equilibria between Products Arising from Complex 1 and Germylene $L^{2}$

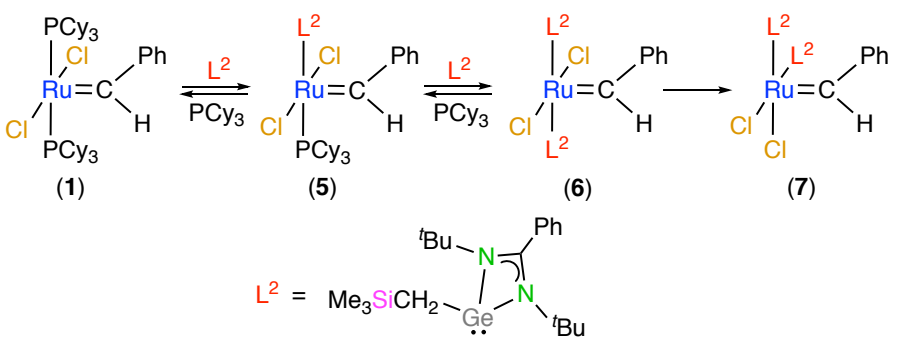




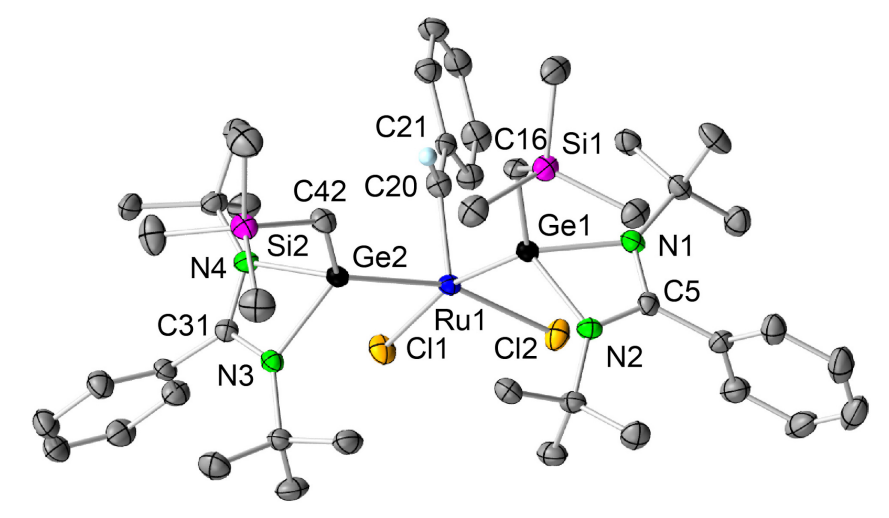

Figure 4. Molecular structure of compound 7 (35\% displacement ellipsoids, $\mathrm{H}$ atoms have been omitted for clarity except that on C20). Selected bond lengths ( $\AA$ ) and angles ('): Ru1-C20 1.862(4), Ru1-Cl1 2.406(1), Ru1-Cl2 2.385(1), Ru1-Ge1 2.3876(5), Ru1-Ge2 2.3904(5), C5-N1 1.313(5), C5-N2 1.341(5), C16-Ge1 1.989(4), C16-Si1 1.869(4), C20-C21 1.466(6), C31-N3 1.345(5), C31-N4 1.318(5), C42-Ge2 1.967(4), C42-Si2 1.872(5), Ge1-N1 1.974(4), Ge1-N2 1.990(3), Ge2-N3 1.964(3), Ge2-N4 1.980(3), C20-Ru1-Cl1 115.1(1), C20-Ru1-Cl2 111.7(1), C20-Ru1-Ge1 83.3(1), C20-Ru1-Ge2 84.0(1), Cl1-Ru1-Ge1 86.27(3), Cl1-Ru1-Ge2 160.95(3), Cl2-Ru1-Cl1 86.24(4), Cl2-Ru1-Ge1 165.03(3), Cl2-Ru1-Ge2 86.65(3), Ge1-Ru1-Ge2 96.37(2).

The XRD molecular structure of complex 7 (Figure 4) exhibits a distorted square pyramidal ligand arrangement around the ruthenium atom, with the benzylidene moiety occupying the apical position, but, contrasting with the structure of complex $\mathbf{3}$, it also shows a mutual cis disposition of the chlorido and germylene ligands. Although it is not unprecedented, such a cis ligand arrangement is unusual for ruthenium alkylidene complexes equipped only with monodentate ligands..$^{1 c, 10 f, 12 a, 13 a, 14 a, 18}$ The ruthenium atom is 0.269 (2) $\AA$ out of the basal plane and the benzylidene ligand, which has the phenyl group in the proximity of the chlorido ligands, has the carbenic carbon (C20) significantly shifted toward the germylene ligands (the $\mathrm{C} 20-\mathrm{Ru}-\mathrm{C} 11$ and $\mathrm{C} 20-\mathrm{Ru}-$ $\mathrm{Cl} 2$ angles are $c a .30^{\circ}$ wider than the $\mathrm{C} 20-\mathrm{Ru}-\mathrm{Ge} 1$ and $\mathrm{C} 20-\mathrm{Ru}-\mathrm{Ge} 2$ angles). The molecule has an approximate (non-crystallographic) $C_{\mathrm{S}}$ symmetry, the plane of symmetry being defined by the atoms of the benzylidene group. The Ru-Ge bond distances of 7, 2.3876(5) and 2.3904(5) $\AA$, are more akin to each other and significantly shorter than those of 3, 2.4575(9) and 2.5043(9) $\AA$, reflecting that the electron-withdrawing character of the chlorido ligands strengthens the trans $\mathrm{Ru}-\mathrm{Ge}$ bonds. The $\mathrm{Ru}-\mathrm{C}$ bond distance, 1.862(4) $\AA$, is slightly longer than that of $\mathbf{3}$ but it is within the range of the $\mathrm{Ru}-\mathrm{C}$ distances reported for related complexes with a cis configuration. ${ }^{10 \mathrm{i}, \mathrm{f}, 12 \mathrm{a}, 13,14}$

According to the cis stereochemistry of 7 , its ${ }^{1} \mathrm{H}$ NMR shows the benzylidene $\mathrm{Ru}=\mathrm{CH}$ proton resonance significantly upfield-shifted ${ }^{10 \mathrm{i}, \mathrm{f}, 12 a, 13,14}$ (14.94 ppm in $\mathrm{C}_{6} \mathrm{D}_{6}$ ) with respect to the 
same signal of complex 3 (20.43 ppm in $\mathrm{C}_{6} \mathrm{D}_{6}$ ) and other related trans complexes. ${ }^{1 \mathrm{a}, 1 \mathrm{~b}, 4,10,12}$ Regarding the germylene ligands, the ${ }^{1} \mathrm{H}$ NMR spectrum revealed that both are equivalent but the $\mathrm{N}^{t} \mathrm{Bu}$ groups of each amidinato fragment are inequivalent, indicating that the approximate $C_{\mathrm{S}}$ symmetry observed in the solid state is maintained in solution.

Aiming at shedding more light on the reaction pathway that leads to complex 7 from complex $\mathbf{1}$ and $\mathbf{L}^{2}$, the reaction was performed and monitored (by NMR) in a similar way as described above for germylene $\mathbf{L}^{\mathbf{1}}$ (Figure 5). However, in contrast with the reaction of $\mathbf{L}^{\mathbf{1}}$, different spectra were obtained $1 \mathrm{~h}$ and $18 \mathrm{~h}$ after each addition of $\mathbf{L}^{2}$.

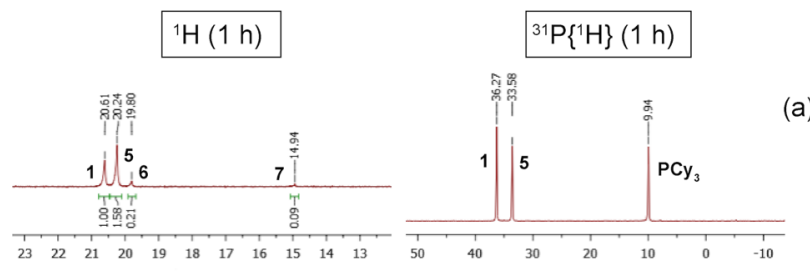

(a)
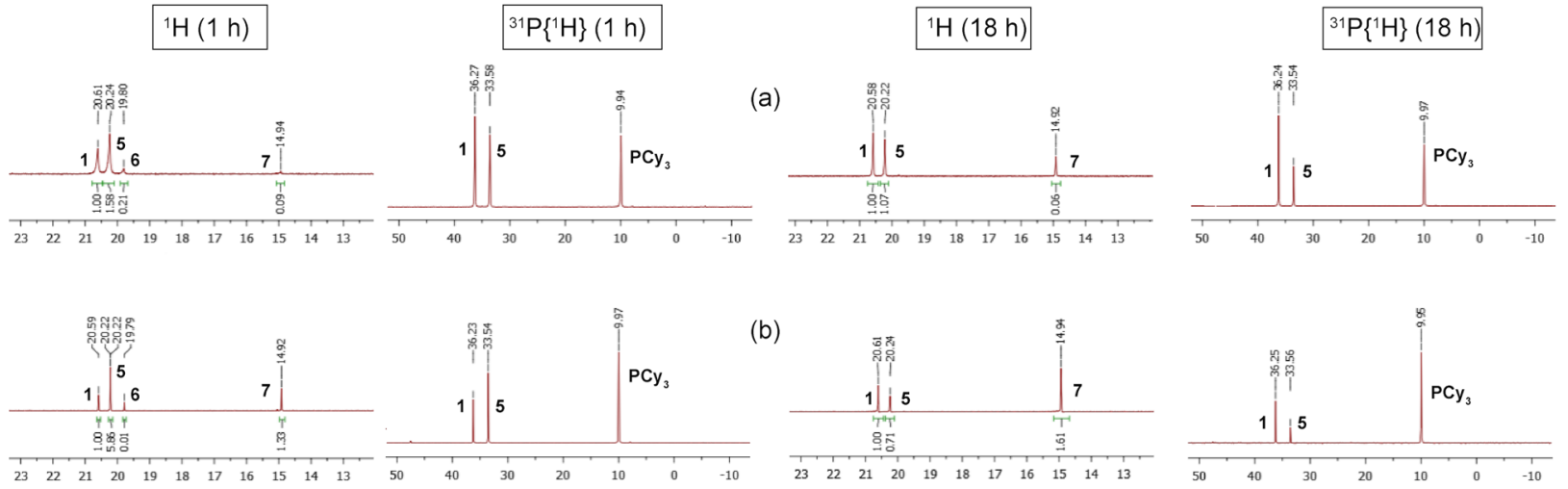

(b)
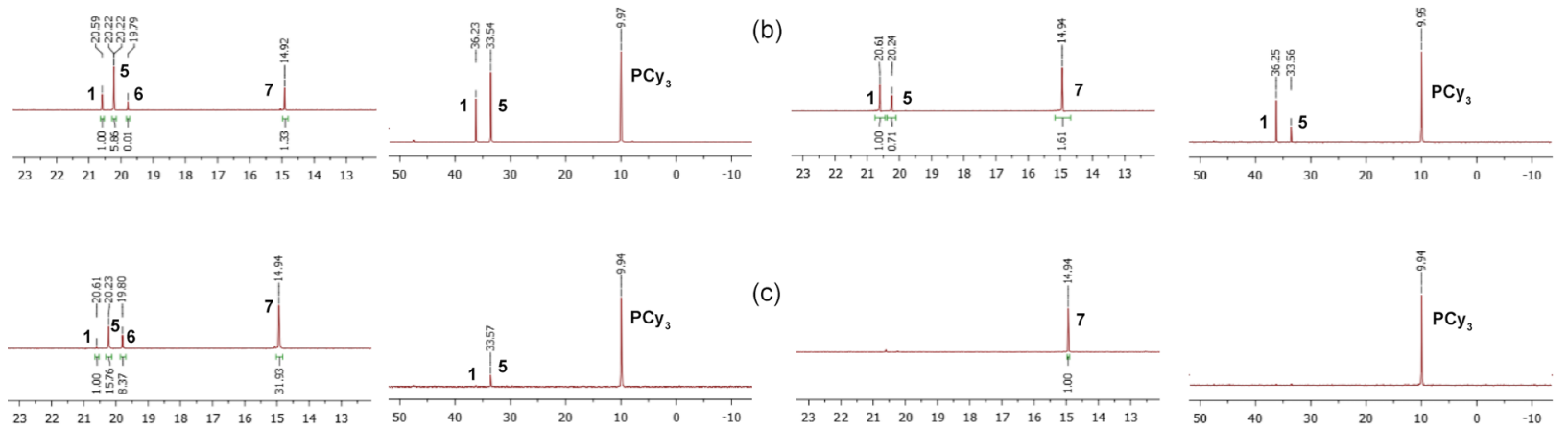

(c)
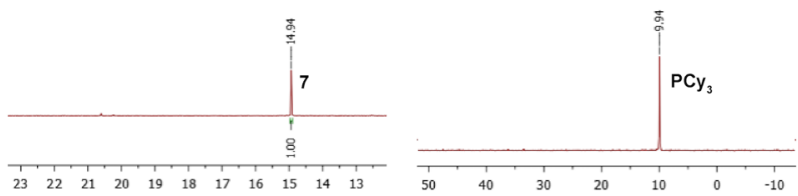

Figure 5. ${ }^{1} \mathrm{H}\left(400.1 \mathrm{MHz}, \mathrm{Ru}=\mathrm{CH}\right.$ region only) and ${ }^{31} \mathrm{P}\left\{{ }^{1} \mathrm{H}\right\}(162.1 \mathrm{MHz}) \mathrm{NMR}$ spectra $(293 \mathrm{~K})$ of samples obtained (a) after mixing complex 1 with one equiv. of $\mathbf{L}^{2}$ in $\mathrm{C}_{6} \mathrm{D}_{6}$ and stirring for $1 \mathrm{~h}$ and $18 \mathrm{~h}$, (b) after adding one equiv. of $\mathbf{L}^{2}$ to the previous solution and stirring for $1 \mathrm{~h}$ and $18 \mathrm{~h}$, and (c) after adding half equiv. of $\mathbf{L}^{2}$ to the previous solution and stirring for $1 \mathrm{~h}$ and $18 \mathrm{~h}$. Chemical shifts $(\delta)$ are given in ppm.

The ${ }^{1} \mathrm{H}$ NMR spectrum recorded $18 \mathrm{~h}$ after the addition of the first equiv. of $\mathbf{L}^{2}$ to a $\mathrm{C}_{6} \mathrm{D}_{6}$ solution of complex 1 (Figure 5a, right) contained three signals in the $\mathrm{Ru}=\mathrm{CH}$ region, corresponding to unreacted $1(20.58 \mathrm{ppm}), 7(14.92 \mathrm{ppm})$ and a new product $(\mathbf{5} ; 20.22 \mathrm{ppm})$, the latter being a $c a .50 \%$ of the mixture. The ${ }^{31} \mathrm{P}\left\{{ }^{1} \mathrm{H}\right\}$ NMR spectrum of this solution also contained three singlets, corresponding to complex 1 (36.2 ppm), free $\mathrm{PCy}_{3}(10.0 \mathrm{ppm})$ and the new product (5; $33.5 \mathrm{ppm})$. Following the same reasoning as that carried out after analyzing the NMR signals of compound $\mathbf{2}$ (vide supra), we identified compound $\mathbf{5}$ as the mixed germylene-phosphane 
derivative trans-[RuCl $\left.2(\mathrm{CHPh})\left(\mathbf{L}^{2}\right)\left(\mathrm{PCy}_{3}\right)\right]$ (Scheme 2). The spectra recorded $18 \mathrm{~h}$ after the addition of another equivalent of $\mathbf{L}^{2}$ to the previous reaction mixture (Figure $5 \mathrm{~b}$, right) led to a significant decrease of the concentrations of $\mathbf{1}$ and $\mathbf{5}$ and an increase of the amount of $\mathbf{7}$, which was the major $\mathrm{Ru}=\mathrm{CHPh}$-containing species in solution (49\%). Accordingly, the ${ }^{31} \mathrm{P}\left\{{ }^{1} \mathrm{H}\right\} \mathrm{NMR}$ spectrum of this solution showed free $\mathrm{PCy}_{3}$ and small amounts of $\mathbf{1}$ and $\mathbf{5}$. Finally, complex $\mathbf{7}$ was practically the only $\mathrm{Ru}=\mathrm{CHPh}$-containing product $18 \mathrm{~h}$ after adding 0.5 equiv. of $\mathbf{L}^{2}$ to the previous solution (2.5 equivalents in total) (Figure $5 \mathrm{c}$, right).

Interestingly, the ${ }^{1} \mathrm{H}$ NMR spectra recorded $1 \mathrm{~h}$ after each addition of $\mathbf{L}^{2}$ (Figure 5a-c, left), beside the signals belonging to $\mathbf{1 , 5}$ and 7, they contained the signals of another (minor) product (6; $19.22 \mathrm{ppm}$ ), which was silent in the ${ }^{31} \mathrm{P}\left\{{ }^{1} \mathrm{H}\right\}$ NMR spectra and that it was not observed after 18 $\mathrm{h}$ of each addition of $\mathbf{L}^{2}$. As the signal at $\delta\left({ }^{1} \mathrm{H}\right) 19.22 \mathrm{ppm}$ corresponds to the $\mathrm{Ru}=\mathrm{CHPh}$ proton of a complex with a trans ligand arrangement, ${ }^{1 \mathrm{a}, 1 \mathrm{~b}, 4,10,12}$ we believe that the transient species $\mathbf{6}$ is $\operatorname{trans} \boldsymbol{s}^{-}$ $\left[\mathrm{RuCl}_{2}(\mathrm{CHPh})\left(\mathbf{L}^{2}\right)_{2}\right]$, which should be a kinetic product because it slowly evolves at room temperature to the cis derivative 7. We subsequently checked that this transformation is irreversible, because complex 6 was never detected (NMR) in solutions of 7. Similar trans-to-cis isomerizations have been reported for a few related complexes, upon thermal treatments or prolonged reaction times at room temperature. ${ }^{12 a, 18,19}$

Therefore, the above-described data strongly support the reaction equilibria depicted in Scheme 2, in which the stepwise replacement of both $\mathrm{PCy}_{3}$ ligands of complex $\mathbf{1}$ by germylene $\mathbf{L}^{2}$, to sequentially give the trans intermediates $\mathbf{5}$ and $\mathbf{6}$, is followed by a trans-to-cis isomerization of 6 into complex 7.

It was unexpected that the final products of the reactions of complex $\mathbf{1}$ with germylenes $\mathbf{L}^{\mathbf{1}}$ (complex 3) and $\mathbf{L}^{2}$ (complex 7) had different structures despite both germylenes are very bulky ( $\mathbf{L}^{1}$ is a bit bulkier than $\mathbf{L}^{2}$ ) and have a similar basicity. Aiming at comparing the thermodynamic stability of the trans $(3)$ and cis (4) stereoisomers of $\left[\mathrm{RuCl}_{2}(\mathrm{CHPh})\left(\mathbf{L}^{1}\right)_{2}\right]$ and the trans $(\mathbf{6})$ and cis (7) stereoisomers of $\left[\mathrm{RuCl}_{2}(\mathrm{CHPh})\left(\mathbf{L}^{2}\right)_{2}\right]$, the molecular structures of these four complexes were optimized by DFT methods (at the wb97xd/cc-pVDZ/SDD $(\mathrm{Ru})$ level of theory). This theoretical study indicated that, for $\left[\mathrm{RuCl}_{2}(\mathrm{CHPh})\left(\mathbf{L}^{1}\right)_{2}\right]$, the trans arrangement (3) is $8.9 \mathrm{kcal} \mathrm{mol}^{-1}$ more stable than the cis (4), whereas for $\left[\mathrm{RuCl}_{2}(\mathrm{CHPh})\left(\mathbf{L}^{2}\right)_{2}\right]$, the trans arrangement $(\mathbf{6})$ is $2.9 \mathrm{kcal} \mathrm{mol}^{-}$ ${ }^{1}$ less stable than the cis (7). Therefore, the reactions of complex $\mathbf{1}$ with $\mathbf{L}^{\mathbf{1}}$ and $\mathbf{L}^{2}$ provide the 
corresponding thermodynamic product (3 and 7, respectively). An analysis of the four optimized structures (Supporting Information, Figures S5-S8) revealed that the geometrical parameters of the trans products $\mathbf{3}$ and $\mathbf{6}$ are very similar, possibly because both germylene ligands are very far from each other within each molecule, while, in order to accommodate the larger $\mathbf{L}^{\mathbf{1}}$ ligands in a cis arrangement, the square pyramidal structure of $\mathbf{4}$ is more distorted (toward a trigonal bipyramid) than that of $\mathbf{7}$, which contains a bit smaller $\mathbf{L}^{2}$ ligands. The Wiberg bond indices ${ }^{20}$ of the $\mathrm{Ru}-\mathrm{Ge}$ bonds of the cis complexes 4 (1.32 and 1.24) and 7 (1.30 and 1.29) are greater than those of the trans complexes 3 (1.18 and 1.15) and 6 (1.15 and 1.19), and, for the isolated complexes $\mathbf{3}$ and $\mathbf{7}$, the dissociation energy ${ }^{21}$ of $\mathbf{L}^{\mathbf{1}}$ from the trans complex $\mathbf{3}$ is considerably smaller (43.0 kcal mol${ }^{-1}$ ) than that of $\mathbf{L}^{2}$ from the cis complex $7\left(52.57 \mathrm{kcal} \mathrm{mol}^{-1}\right)$. Therefore, in the absence of steric hindrances, the electron-withdrawing chlorido ligands prefer to be trans to the strong electron-donor germylene ligands and such a ligand arrangement results in shorter and stronger $\mathrm{Ru}-\mathrm{Ge}$ bonds. In our case, this occurs only in the cis complex 7. Theoretical studies on related ruthenium indenylidene complexes have revealed the existence of a linear relationship between the size of the ancillary ligands and the relative stability of the trans and cis isomers. $^{18 a}$

Having complexes $\mathbf{3}$ and $\mathbf{7}$ in hand, we tested them as catalyst precursors for olefin metathesis. The ring-closing metathesis (RCM) of diethyl 2,2-diallylmalonate to cyclopent-3-ene1,1-dicarboxylate and the ring-opening metathesis polymerization (ROMP) of norbornene were tested as benchmark catalytic reactions, under the standard reaction conditions used by Grubbs and co-workers ${ }^{22}$ for RCM and by Hermann and co-workers ${ }^{10 \mathrm{k}}$ for ROMP, that is, $1 \mathrm{~mol} \%$ catalyst loading in $\mathrm{CD}_{2} \mathrm{Cl}_{2}$ at $30{ }^{\circ} \mathrm{C}(\mathrm{RCM})$ or $25{ }^{\circ} \mathrm{C}(\mathrm{ROMP})$. In all cases (Tables $\mathrm{S} 1$ and $\left.\mathrm{S} 2\right)$, the substrate conversion was low or moderate at the initial stages of the reactions (5-15 min) and it increased very slowly (or not at all) at longer reaction times $(2-24 \mathrm{~h})$, hinting to catalyst decomposition. These catalytic activities are very low compared with those afforded by benchmark olefin metathesis ruthenium alkylidene catalysts, which generally render full conversions within the first $30 \mathrm{~min}$ in the same conditions. ${ }^{10 \mathrm{k}, 22}$ The low catalytic activities found for $\mathbf{3}$ and $\mathbf{7}$ might also be caused by the difficulty of the complexes to generate (by ligand dissociation) the 14-electron species necessary to initiate the catalytic cycles, as a consequence of the strong electron-donation of the germylene ligands. Low catalytic activities at room temperature have also been reported for analogous bis(NHC) ruthenium complexes, ${ }^{3 a, 10 \mathrm{~d}, \mathrm{e}, \mathrm{g}}$ but this issue has been circumvented raising the working temperature. Having this in mind, we also performed the RCM reaction at $80{ }^{\circ} \mathrm{C}$ in 
toluene- $d_{8}$, but, unfortunately, the higher temperature deactivated complex $\mathbf{3}$ and it did not improve the catalytic activity of 7 (Table S1). Most probably, the high temperature reduces the stability of the catalyst precursors and/or that of the free germylenes (released from the catalyst precursors), which are very reactive molecules. Lowering the temperature to $50{ }^{\circ} \mathrm{C}$ gave similar results for both catalyst precursors.

\section{CONCLUDING REMARKS}

In summary, the first Grubbs-I-type carbene complexes supported by germylene ligands, namely, the bis(germylene) derivatives trans-[RuCl$\left.(\mathrm{CHPh})\left(\mathbf{L}^{1}\right)_{2}\right](\mathbf{3})$ and cis- $\left[\mathrm{RuCl}_{2}(\mathrm{CHPh})\left(\mathbf{L}^{2}\right)_{2}\right]$ (7), have been prepared in high yields from the first-generation Grubbs' catalyst trans$\left[\mathrm{RuCl}_{2}(\mathrm{CHPh})\left(\mathrm{PCy}_{3}\right)_{2}\right]$ (1). DFT calculations have shown that, for complexes of this kind, the most stable stereochemistry is cis only when in this arrangement there is not steric hindrance between the germylene ligands; therefore, the different stereochemistry of $\mathbf{3}$ and $\mathbf{7}$ is a consequence of the different volume of $\mathbf{L}^{1}$ and $\mathbf{L}^{2}$ (the former is larger than the latter).

Although the mixed ligand complexes trans- $\left[\mathrm{RuCl}_{2}(\mathrm{CHPh})\left(\mathbf{L}^{1}\right)\left(\mathrm{PCy}_{3}\right)\right]$ (2) and trans$\left[\mathrm{RuCl}_{2}(\mathrm{CHPh})\left(\mathbf{L}^{2}\right)\left(\mathrm{PCy}_{3}\right)\right](\mathbf{5})$ and the disubstituted derivative trans- $\left[\mathrm{RuCl}_{2}(\mathrm{CHPh})\left(\mathbf{L}^{2}\right)_{2}\right](\mathbf{6})$ could not be isolated, they have been identified as reaction intermediates by NMR, which has confirmed the reaction sequences $\mathbf{1} \rightarrow \mathbf{2} \rightarrow \mathbf{3}$ (reaction of $\mathbf{1}$ with $\mathbf{L}^{\mathbf{1}}$ ) and $\mathbf{1} \rightarrow \mathbf{5} \rightarrow \mathbf{6} \rightarrow \mathbf{7}$ (reaction of $\mathbf{1}$ with $\left.\mathbf{L}^{2}\right)$.

Complexes 3 and 7 have been tested as catalyst precursors for the RCM of diethyl 2,2diallylmalonate and the ROMP of norbornene, but the catalytic activities observed at the initial stages of the reactions rapidly slowed down, hinting to catalyst decomposition.

These results, while not relevant for the point of view of catalytic activity, showed for the first time that heavier tetrylenes, in this case two germylenes, can be used as ancillary ligands for the preparation of Grubbs-type complexes. Having in mind the tremendous potential and versatility that this type of ligands has shown in the last few years (a plethora of silylenes, germylenes and stannylenes, having a great variety of electronic and steric characteristics, are currently available), the present contribution opens new opportunities for the design of organometallic complexes and olefin-metathesis catalysts. 


\section{EXPERIMENTAL SECTION}

General Procedures. All reactions and manipulations were carried out under argon in a dry glove-box equipped with a vacuum line. Solvents were dried over appropriate desiccating reagents, distilled under argon, and transferred to the glove-box before use. Germylenes $\mathrm{Ge}\left({ }^{t} \mathrm{Bu}_{2}\right.$ bzam ${ }^{t} \mathrm{Bu}\left(\mathbf{L}^{1}\right)^{11 \mathrm{c}}$ and $\mathrm{Ge}\left({ }^{t} \mathrm{Bu}_{2}\right.$ bzam $) \mathrm{Cl}^{23}$ were prepared following published procedures. All remaining reagents/solvents were purchased from commercial sources. The reaction products were vacuum-dried for several hours prior to being weighted and analyzed. NMR spectra were run on Bruker NAV-400 and AV-300 instruments; the standards used were the residual protic solvent resonance for ${ }^{1} \mathrm{H}\left[\delta\left(\mathrm{C}_{6} H \mathrm{D}_{5}\right)=7.16 \mathrm{ppm}\right]$, the solvent resonance for ${ }^{13} \mathrm{C}\left[\delta\left(C_{6} \mathrm{D}_{6}\right)=128.10 \mathrm{ppm}\right]$ and aqueous $85 \% \mathrm{H}_{3} \mathrm{PO}_{4}$ as external reference for ${ }^{31} \mathrm{P}\left[\delta\left(\mathrm{H}_{3} P \mathrm{O}_{4}\right)=0.00 \mathrm{ppm}\right]$. Microanalyses were obtained with a Perkin-Elmer 2400 microanalyzer. High-resolution mass spectra (HRMS) were obtained with a Bruker Impact II mass spectrometer operating in the ESI-Q-ToF positive mode.

$\mathbf{G e}\left({ }^{t} \mathbf{B u}_{2} \mathbf{b z a m}\right) \mathrm{CH}_{2} \mathrm{SiMe}_{3}\left(\mathbf{L}^{2}\right)$. A pentane solution of $\mathrm{LiCH}_{2} \mathrm{SiMe}_{3}(1.0 \mathrm{~mL}, 1 \mathrm{M}, 1.0$ mmol) was added to a solution of $\mathrm{Ge}\left({ }^{(} \mathrm{Bu}_{2} \mathrm{bzam}\right) \mathrm{Cl}(339 \mathrm{mg}, 1.0 \mathrm{mmol})$ in toluene $(2 \mathrm{~mL})$. The resulting suspension was stirred at room temperature for $1 \mathrm{~h}$. The solvent was removed under reduced pressure and the residue was extracted into 2:1 toluene:hexane $(3 \times 3 \mathrm{~mL})$. Solvent removal allowed the isolation of $\mathbf{L}^{2}$ as a light yellow solid (384 mg, $98 \%$ ). Anal. (\%) Calcd for $\mathrm{C}_{19} \mathrm{H}_{34} \mathrm{GeN}_{2} \mathrm{Si}\left(M=391.20 \mathrm{~g} \mathrm{~mol}^{-1}\right): \mathrm{C}, 58.33 ; \mathrm{H}, 8.76 ; \mathrm{N}, 7.16$; found $\mathrm{C}, 58.12 ; \mathrm{H}, 8.61 ; \mathrm{N}, 7.23$. ${ }^{1} \mathrm{H}$ NMR $\left(\mathrm{C}_{6} \mathrm{D}_{6}, 300.1 \mathrm{MHz}, 293 \mathrm{~K}\right): \delta 7.11-6.99$ (m, $5 \mathrm{H}, 5 \mathrm{CH}$ of Ph), 1.03 (s, $18 \mathrm{H}, 6 \mathrm{CH}_{3}$ of 2 $\left.\mathrm{N}^{t} \mathrm{Bu}\right), 0.74\left(\mathrm{~s}, 2 \mathrm{H}, \mathrm{CH}_{2}\right), 0.36\left(\mathrm{~s}, 9 \mathrm{H}, 3 \mathrm{CH}_{3}\right.$ of $\left.\mathrm{SiMe}_{3}\right) .{ }^{13} \mathrm{C}\left\{{ }^{1} \mathrm{H}\right\} \mathrm{NMR}\left(\mathrm{C}_{6} \mathrm{D}_{6}, 75.5 \mathrm{MHz}, 293 \mathrm{~K}\right)$ : $\delta 163.7(\mathrm{NCN}), 136.9\left(C_{\text {ipso }}\right.$ of $\left.\mathrm{Ph}\right), 130.1-127.6(5 \mathrm{CH}$ of $\mathrm{Ph}), 53.2(2 C$ of $2 \mathrm{~N} t \mathrm{Bu}), 32.1\left(6 \mathrm{CH}_{3}\right.$ of $\left.2 \mathrm{~N}^{t} \mathrm{Bu}\right), 22.3\left(\mathrm{CH}_{2}\right), 2.1\left(3 \mathrm{CH}_{3}\right.$ of $\left.\mathrm{SiMe}_{3}\right)$. Several phenyl $\mathrm{CH}$ signals overlap with that of the $\mathrm{C}_{6} \mathrm{D}_{6}$ solvent.

Trans- $\left[\mathbf{R u C l}_{2}(\mathbf{C H P h})\left\{\mathbf{G e}\left({ }^{t} \mathbf{B u}_{2} \mathbf{b z a m}\right)^{t} \mathbf{B u}\right\}_{2}\right](3)$. Toluene $(1 \mathrm{~mL})$ was added to a mixture of 1 (100 mg, $0.122 \mathrm{mmol})$ and $\mathbf{L}^{1}(101 \mathrm{mg}, 0.281 \mathrm{mmol})$. The original purple suspension changed immediately to light red and it was stirred at room temperature for $18 \mathrm{~h}$. The solvent was removed under reduced pressure and the residue was washed with hexane $(3 \times 1 \mathrm{~mL})$ to give 3 as a light red solid (98 mg, $82 \%$ ). Anal. (\%) Calcd for $\mathrm{C}_{45} \mathrm{H}_{70} \mathrm{Cl}_{2} \mathrm{Ge}_{2} \mathrm{~N}_{4} \mathrm{Ru}\left(M=984.29 \mathrm{~g} \mathrm{~mol}^{-1}\right)$ : C, 54.91; $\mathrm{H}$, 7.17; N, 5.69; found C, 54.85; H, 7.01; N, 5.54. (+)-ESI HRMS: found (calcd) $\mathrm{m} / z$ 985.2378 (985.2366) $[M-\mathrm{H}]^{+} .{ }^{1} \mathrm{H}$ NMR $\left(\mathrm{C}_{6} \mathrm{D}_{6}, 300.1 \mathrm{MHz}, 293 \mathrm{~K}\right): \delta 20.47$ (s, $1 \mathrm{H}, \mathrm{CH}$ of $\left.\mathrm{Ru}=\mathrm{CH}\right), 8.72$ 
(d, $J=7.3 \mathrm{~Hz}, 2 \mathrm{H}, 2 \mathrm{CH}$ of $\mathrm{Ph}), 7.94(\mathrm{~d}, J=7.8 \mathrm{~Hz}, 2 \mathrm{H}, 2 \mathrm{CH}$ of Ph), $7.36(\mathrm{t}, J=7.3 \mathrm{~Hz}, 1 \mathrm{H}$, $\mathrm{CH}$ of $\mathrm{Ph}), 7.22(\mathrm{t}, J=7.6 \mathrm{~Hz}, 2 \mathrm{H}, \mathrm{CH}$ of $\mathrm{Ph}), 7.02(\mathrm{~d}, J=7.3 \mathrm{~Hz}, 2 \mathrm{H}, \mathrm{CH}$ of Ph), 6.96-6.86 (m, $6 \mathrm{H}, \mathrm{CH}$ of $\mathrm{Ph}), 1.69\left(\mathrm{~s}, 18 \mathrm{H}, 6 \mathrm{CH}_{3}\right.$ of $\left.2 \mathrm{Ge}^{t} \mathrm{Bu}\right), 1.15\left(\mathrm{~s}, 36 \mathrm{H}, 12 \mathrm{CH}_{3}\right.$ of $\left.4 \mathrm{~N} \mathrm{~N}^{\prime} \mathrm{Bu}\right) .{ }^{13} \mathrm{C}\left\{{ }^{1} \mathrm{H}\right\} \mathrm{NMR}$ $\left(\mathrm{C}_{6} \mathrm{D}_{6}, 100.6 \mathrm{MHz}, 293 \mathrm{~K}\right): \delta 290.0(\mathrm{Ru}=\mathrm{CH}), 169.7(\mathrm{NCN}), 153.9\left(C_{\mathrm{ppso}}\right.$ of $\left.\mathrm{Ru}=\mathrm{CPh}\right), 134.7(2$ $C_{\text {ipso }}$ of $2 \mathrm{Ph}$ ), 132.4-127.3 (15 CH of $3 \mathrm{Ph}$ ), 53.4 (4 $C$ of $4 \mathrm{~N} t \mathrm{Bu}$ ), 36.7 (2 $C$ of $2 \mathrm{Ge}^{t} \mathrm{Bu}$ ), 32.2 (6 $\mathrm{CH}_{3}$ of $\left.4 \mathrm{~N}^{t} \mathrm{Bu}\right), 29.9\left(6 \mathrm{CH}_{3}\right.$ of $\left.2 \mathrm{Ge}^{t} \mathrm{Bu}\right)$. Several phenyl $\mathrm{CH}$ signals overlap with that of the $\mathrm{C}_{6} \mathrm{D}_{6}$ solvent.

Cis-[RuCl $\left.{ }_{2}(\mathbf{C H P h})\left\{\mathbf{G e}\left({ }^{(} \mathbf{B u}_{2} \text { bzam }\right) \mathbf{C H}_{2} \mathbf{S i M e}_{3}\right\}_{2}\right]$ (7). Toluene $(1 \mathrm{~mL})$ was added to a mixture of $\mathbf{1}(100 \mathrm{mg}, 0.122 \mathrm{mmol})$ and $\mathbf{L}^{2}(110 \mathrm{mg}, 0.281 \mathrm{mmol})$. The original purple suspension changed immediately to dark green and it was stirred at room temperature for $18 \mathrm{~h}$. The solvent was removed under reduced pressure and the residue was washed with hexane $(3 \times 1 \mathrm{~mL})$ to give 7 as a green solid (113 mg, $89 \%$ ). Anal. (\%) Calcd for $\mathrm{C}_{45} \mathrm{H}_{74} \mathrm{Cl}_{2} \mathrm{Ge}_{2} \mathrm{~N}_{4} \mathrm{RuSi}_{2}\left(M=1044.49 \mathrm{~g} \mathrm{~mol}^{-}\right.$ 1): C, 51.75; H, 7.14; N, 5.36; found C, 51.88; H, 7.03; N, 5.48. (+)-ESI HRMS: found (calcd) $\mathrm{m} / \mathrm{z}$ 1011.2578 (1011.2606) $[M-\mathrm{Cl}]^{+} .{ }^{1} \mathrm{H}$ NMR $\left(\mathrm{C}_{6} \mathrm{D}_{6}, 400.1 \mathrm{MHz}, 293 \mathrm{~K}\right): \delta 14.94$ (s, $1 \mathrm{H}, \mathrm{CH}$ of $\mathrm{Ru}=\mathrm{CH}), 8.34(\mathrm{~d}, J=7.4 \mathrm{~Hz}, 2 \mathrm{H}, \mathrm{CH}$ of $\mathrm{Ph}), 7.33-7.18(\mathrm{~m}, 7 \mathrm{H}, \mathrm{CH}$ of Ph), 6.97-6.85 (m, $6 \mathrm{H}$, $\mathrm{CH}$ of $\mathrm{Ph}), 1.37\left(\mathrm{~s}, 22 \mathrm{H}, 6 \mathrm{CH}_{3}\right.$ of $2 \mathrm{~N}^{t} \mathrm{Bu}$ and $\left.2 \mathrm{CH}_{2}\right), 0.82\left(\mathrm{~s}, 18 \mathrm{H}, 6 \mathrm{CH}_{3}\right.$ of $\left.2 \mathrm{~N}^{\prime} \mathrm{Bu}\right), 0.43(\mathrm{~s}, 18$ $\mathrm{H}, 6 \mathrm{CH}_{3}$ of $\left.2 \mathrm{SiMe}_{3}\right) \cdot{ }^{13} \mathrm{C}\left\{{ }^{1} \mathrm{H}\right\} \mathrm{NMR}\left(\mathrm{C}_{6} \mathrm{D}_{6}, 100.6 \mathrm{MHz}, 293 \mathrm{~K}\right): \delta 277.6(\mathrm{Ru}=\mathrm{CH}), 169.1(\mathrm{NCN})$, $150.7\left(C_{\text {ipso }}\right.$ of $\left.\mathrm{Ru}=\mathrm{CPh}\right), 134.2\left(2 C_{\text {ipso }}\right.$ of $\left.2 \mathrm{Ph}\right), 132.7-127.1(15 C \mathrm{H}$ of $3 \mathrm{Ph}), 54.7$ (2C of 2 $\left.\mathrm{N}^{t} \mathrm{Bu}\right), 54.5\left(2 \mathrm{C}\right.$ of $\left.2 \mathrm{~N}^{t} \mathrm{Bu}\right), 32.8\left(6 \mathrm{CH}_{3}\right.$ of $\left.2 \mathrm{~N}^{t} \mathrm{Bu}\right), 31.5\left(6 \mathrm{CH}_{3}\right.$ of $\left.2 \mathrm{~N}^{t} \mathrm{Bu}\right), 18.7\left(2 \mathrm{CH}_{2}\right), 2.3(6$ $\mathrm{CH}_{3}$ of $2 \mathrm{SiMe}_{3}$ ). Several phenyl $\mathrm{CH}$ signals overlap with that of the $\mathrm{C}_{6} \mathrm{D}_{6}$ solvent.

NMR Monitoring of the Reactions of 1 with $\mathbf{L}^{1}$ and $\mathbf{L}^{2}$. Two J. Young-sealed NMR tubes were loaded with $\mathbf{1}$ (50 mg, $0.061 \mathrm{mmol}), \mathbf{L}^{1}(22 \mathrm{mg}, 0.061 \mathrm{mmol})$ or $\mathbf{L}^{2}(24 \mathrm{mg}, 0.061$ $\mathrm{mmol})$, and $\mathrm{C}_{6} \mathrm{D}_{6}(0.4 \mathrm{~mL})$. The resulting solutions were stirred at room temperature and analyzed by ${ }^{1} \mathrm{H}$ and ${ }^{31} \mathrm{P}\left\{{ }^{1} \mathrm{H}\right\}$ NMR after $1 \mathrm{~h}$ and $18 \mathrm{~h}$. Another equivalent of $\mathbf{L}^{1}\left(22 \mathrm{mg}, 0.061 \mathrm{mmol}\right.$ ) or $\mathbf{L}^{2}$ (24 $\mathrm{mg}, 0.061 \mathrm{mmol}$ ), as appropriate, was then added to each NMR tube and the resulting solutions were analyzed by ${ }^{1} \mathrm{H}$ and ${ }^{31} \mathrm{P}\left\{{ }^{1} \mathrm{H}\right\}$ NMR after $1 \mathrm{~h}$ and $18 \mathrm{~h}$. Finally, 0.5 equivalents of $\mathbf{L}^{1}$ (11 $\mathrm{mg}, 0.031 \mathrm{mmol})$ or $\mathbf{L}^{2}$ (12 $\left.\mathrm{mg}, 0.031 \mathrm{mmol}\right)$, as appropriate, were then added to each NMR tube and the resulting solutions were analyzed by ${ }^{1} \mathrm{H}$ and ${ }^{31} \mathrm{P}\left\{{ }^{1} \mathrm{H}\right\} \mathrm{NMR}$ after $1 \mathrm{~h}$ and $18 \mathrm{~h}$. The resulting NMR spectra are shown in Figures 3 (for $\mathbf{L}^{1}$ ) and 5 (for $\mathbf{L}^{2}$ ). 
Reaction of 1 with 3. A J. Young-sealed NMR tube was loaded with 1 ( $25 \mathrm{mg}, 0.031$ mmol), 3 (30 mg, $0.031 \mathrm{mmol})$ and $\mathrm{C}_{6} \mathrm{D}_{6}(0.3 \mathrm{~mL})$, and the solution was stirred at room temperature for $6 \mathrm{~h}$. The resulting ${ }^{1} \mathrm{H}$ and ${ }^{31} \mathrm{P}\left\{{ }^{1} \mathrm{H}\right\}$ NMR spectra are shown in Figure S4. Longer reaction times $(24 \mathrm{~h})$ or a higher temperature $\left(30 \mathrm{~min}\right.$ at $\left.100{ }^{\circ} \mathrm{C}\right)$ rendered similar NMR spectra.

Reaction of 1 with 7. A J. Young-sealed NMR tube was loaded with 1 ( $25 \mathrm{mg}, 0.031$ mmol), $7(31 \mathrm{mg}, 0.031 \mathrm{mmol})$ and $\mathrm{C}_{6} \mathrm{D}_{6}(0.3 \mathrm{~mL})$, and the solution was stirred at room temperature for $6 \mathrm{~h}$. The resulting ${ }^{1} \mathrm{H}$ and ${ }^{31} \mathrm{P}\left\{{ }^{1} \mathrm{H}\right\}$ NMR spectra showed only the signals of the starting reagents. Longer reaction times $(24 \mathrm{~h})$ rendered similar NMR spectra, but a higher temperature $\left(30 \mathrm{~min}\right.$ at $100{ }^{\circ} \mathrm{C}$ ) led to the disappearance of complex 7 and the formation of a mixture of unidentified species.

Catalytic RCM of Diethyl 2,2-Diallylmalonate. A J. Young-sealed NMR tube was loaded with a stock solution of the appropriate catalyst precursor 3 or $7\left(81 \mu \mathrm{L}, 0.0097 \mathrm{M}^{\text {in }} \mathrm{CD}_{2} \mathrm{Cl}_{2}, 0.79\right.$ $\mu \mathrm{mol})$, diethyl 2,2-diallylmalonate $(19 \mu \mathrm{L}, 0.079 \mathrm{mmol})$ and $\mathrm{CD}_{2} \mathrm{Cl}_{2}$ or toluene- $d_{8}(0.75 \mathrm{~mL})$. The tube was placed in an oil bath thermostated at $30{ }^{\circ} \mathrm{C}\left(\mathrm{CD}_{2} \mathrm{Cl}_{2}\right.$ solutions) or $80{ }^{\circ} \mathrm{C}$ (toluene- $d_{8}$ solutions) and ${ }^{1} \mathrm{H}$ NMR spectra were recorded at the intervals indicated in Table S1. The conversion to diethyl cyclopent-3-ene-1,1-dicarboxylate was determined from the integrals of the methylene protons of the starting material, $\delta\left({ }^{1} \mathrm{H}\right) 2.61(\mathrm{dt})$ in $\mathrm{CD}_{2} \mathrm{Cl}_{2}$ or $2.73(\mathrm{dt})$ in toluene- $d_{8}$, and the final product, $\delta\left({ }^{1} \mathrm{H}\right) 2.98(\mathrm{~s})$ in $\mathrm{CD}_{2} \mathrm{Cl}_{2}$ or 3.05 (s) in toluene- $d_{8}$.

Catalytic ROMP of Norbornene. A J. Young-sealed NMR tube was loaded with the appropriate catalyst precursor $3(6.2 \mathrm{mg}, 6.3 \mu \mathrm{mol})$ or 7 (6.6 mg, $6.3 \mu \mathrm{mol})$, norbornene (59 mg, $0.63 \mathrm{mmol})$ and $\mathrm{CD}_{2} \mathrm{Cl}_{2}(0.5 \mathrm{~mL})$. The tube was placed in an oil bath thermostated at $25^{\circ} \mathrm{C}$ and ${ }^{1} \mathrm{H}$ NMR spectra were recorded at the intervals indicated in Table S2. The conversion to the polymer was determined from the integrals of olefinic protons of the starting material, $\delta\left({ }^{1} \mathrm{H}\right) 5.99(\mathrm{~m})$, and the final product, $\delta\left({ }^{1} \mathrm{H}\right) 5.36(\mathrm{~m})$.

X-Ray Diffraction Analyses. Crystals of $\mathbf{3}$ and $\mathbf{7} \cdot \mathrm{CH}_{2} \mathrm{Cl}_{2}$ were analyzed by X-ray diffraction. A selection of crystal, measurement and refinement data is given in Table S3. Diffraction data were collected on an Oxford Diffraction Xcalibur Onyx Nova single crystal diffractometer with $\mathrm{CuK \alpha}$ radiation. Empirical absorption corrections were applied using the SCALE3 ABSPACK algorithm as implemented in CrysAlisPro RED. ${ }^{24}$ The structures were solved 
with SIR-97. ${ }^{25}$ Isotropic and full matrix anisotropic least square refinements were carried out using SHELXL. ${ }^{26}$ All non-H atoms were refined anisotropically. $\mathrm{H}$ atoms were set in calculated positions and were refined riding on their parent atoms. The WINGX program system ${ }^{27}$ was used throughout the structure determinations. The molecular plots were made with MERCURY. ${ }^{28}$ CCDC deposition numbers: $1558784(3)$ and $1558785\left(7 \cdot \mathrm{CH}_{2} \mathrm{Cl}_{2}\right)$.

Theoretical Calculations. DFT calculations were carried out using the wB97XD functional, ${ }^{29}$ which includes the second generation of Grimme's dispersion interaction correction ${ }^{30}$ as well as long-range interactions effects. This functional reproduces the local coordination geometry of transition metal compounds very well and it also corrects the systematic overestimation of non-bonded distances seen for all the density functionals that do not include estimates of dispersion. ${ }^{31}$ The Stuttgart-Dresden relativistic effective core potential and the associated basis sets (SDD) were used for the Ru atom. ${ }^{32}$ The basis set used for the remaining atoms was the cc-pVDZ. ${ }^{33}$ The stationary points were fully optimized in gas phase and confirmed as energy minima (all positive eigenvalues) by analytical calculation of frequencies. All calculations were carried out with the Gaussian09 package. ${ }^{34}$

\section{ASSOCIATED CONTENT}

The Supporting Information is available free of charge on the ACS Publications website at DOI: 10.1021/acs.organomet.Xxxxxxx.

${ }^{1} \mathrm{H}$ and ${ }^{13} \mathrm{C}\left\{{ }^{1} \mathrm{H}\right\}$ NMR spectra of $\mathbf{L}^{2}, 3$ and 7 (Figures $\mathrm{S} 1-\mathrm{S} 3$ ); ${ }^{1} \mathrm{H}$ and ${ }^{31} \mathrm{P}\left\{{ }^{1} \mathrm{H}\right\}$ NMR spectra of the outcome of the reaction of $\mathbf{1}$ with $\mathbf{3}$ (Figure S4); images and metric parameters of the DFToptimized structures of 3, 4, 6 and 7 (Figures S5-S8); results of catalytic experiments (Tables S1

and S2); and crystal, measurement and refinement data for the compounds studied by XRD (Table S3) (PDF).

Atomic coordinates for the calculated structures (XYZ).

\section{Accession Codes}

CCDC 1558784 and 1558785 contain the supplementary crystallographic data for this paper. These data can be obtained free of charge via www.ccdc.cam.ac.uk/data_request/cif, or by emailing data_request@ccdc.cam.ac.uk, or by contacting The Cambridge Crystallographic Data Centre, 12 Union Road, Cambridge CB2 1EZ, UK; fax: +44 1223336033. 


\section{AUTHOR INFORMATION}

\section{Corresponding Author}

*E-mail for J.A.C.: jac@uniovi.es

*E-mail for P.G.-A.: pga@uniovi.es

\section{ORCID}

Lucía Álvarez-Rodríguez: 0000-0003-3176-3855

Javier A. Cabeza: 0000-0001-8563-9193

Pablo García-Álvarez: 0000-0002-5024-3874

Enrique Pérez-Carreño: 0000-0001-8042-0678

\section{Notes}

The authors declare no competing financial interest.

\section{ACKNOWLEDGMENTS}

This work has been supported by MINECO-FEDER (CTQ2016-75218-P, MAT2013-40950-R, RYC2012-10491 and CTQ2016-81797-REDC) and Gobierno del Principado de Asturias (GRUPIN14-009 and GRUPIN14-060) research grants. L.A.-R. thanks the University of Oviedo for a predoctoral fellowship.

\section{REFERENCES}

(1) See, for example: (a) Schwab, P.; Grubbs, R. H.; Ziller, J. W. J. Am. Chem. Soc. 1996, 118, 100-110. (b) Schwab, P.; France, M. B.; Ziller, J. W.; Grubbs, R. H. Angew. Chem. Int. Ed. 1995, 34, 2039-2041. (c) Nguyen, S. T.; Grubbs, R. H.; Ziller, J. W. J. Am. Chem. Soc. 1993, 115, 9858-9859. (d) Nguyen, S. T.; Johnson, L. K.; Grubbs, R. H.; Ziller, J. W. J. Am. Chem. Soc. 1992, 114, 3974-3975.

(2) For general reviews on olefin metathesis, see: (a) Handbook of Metathesis, 2nd Ed.; Grubbs, R. H.; Wenzel, A. G.; O’Leary, D. J.; Khosravi, E., Eds.; Wiley-VCH: Weinheim, 2015. (b) Clavier, H.; Grela, K.; Kirschning, A.; Mauduit, M. Angew. Chem. Int. Ed. 2007, 46, 6786-6801.

(3) For reviews on NHC-ruthenium olefin metathesis catalysts, see: (a) Vougioukalakis, G. C.; Grubbs, R. H. Chem. Rev. 2010, 110, 1746-1787. (b) Samojłowicz, C.; Bieniek, M.; Grela, K. Chem. Rev. 2009, 109, 3708-3742. 
(4) See, for example: (a) Sanford, M. S.; Love, J. A.; Grubbs, R. H. J. Am. Chem. Soc. 2001, 123, 6543-6554. (b) Sanford, M. S.; Ulman, M.; Grubbs, R. H. J. Am. Chem. Soc. 2001, 123, $749-750$.

(5) (a) Schmidt, M.; Blom, B.; Szilvási, T.; Schomacker, R.; Driess, M. Eur. J. Inorg. Chem. 2017, 1284-1291. (b) Benedek, Z.; Szilvási, T. Organometallics 2017, 36, 1591-1600. (c) Gallego, D.; Brück, A.; Irran, E.; Meier, F.; Kaupp, M.; Driess, M.; Hartwig, J. F. J. Am. Chem. Soc. 2013, 135, 15617-15626. (d) Wang, W.; Inoue, S.; Enthaler, S.; Driess, M. Angew. Chem. Int. Ed. 2012, 51, 6167-6171. (e) Brück, A.; Gallego, D.; Wang, W.; Irran, E.; Driess, M.; Hartwig, J. F. Angew. Chem. Int. Ed. 2012, 51, 11478-11482. (f) Wang, W.; Inoue, S.; Irran, E.; Driess, M. Angew. Chem. Int. Ed. 2012, 51, 3691-3694.

(6) (a) Zhou, Y.-P.; Raoufmoghaddam, S.; Szilvási, T.; Driess, M. Angew. Chem. Int. Ed. 2016, 55, 12868-12872. (b) Troadec, T.; Prades, A.; Rodríguez, R.; Mirgalet, R.; Baceiredo, A.; SaffonMerceron, N.; Branchadell, V.; Kato, T. Inorg. Chem. 2016, 55, 8234-8240. (c) Benedek, Z.; Szilvási, T. RSC Adv. 2015, 5, 5077-5086. (d) Tan, G.; Enthaler, S.; Inoue, S.; Blom, B.; Driess, M. Angew. Chem. Int. Ed. 2015, 54, 2214-2218. (e) Gallego, D.; Inoue, S.; Blom, B.; Driess, M. Organometallics 2014, 33, 6885-6897. (f) Cabeza, J. A.; García-Álvarez, P.; Pérez-Carreño, E.; Polo, D. Chem. Eur. J. 2014, 20, 8654-8663. (g) Meltzer, A.; Inoue, S.; Präsang, C.; Driess, M. J. Am. Chem. Soc. 2010, 132, 3038-3046. (h) Meltzer, A.; Präsang, C.; Driess, M. J. Am. Chem. Soc. 2009, 131, 7232-7233.

(7) Cade, I. A.; Hill, A. F.; Kämpfe, A.; Wagler, J. Organometallics 2010, 29, 4012-4017.

(8) NHCs of the imidazol(in)-2-ylidene type.

(9) (a) A search on the Cambridge Structure Database (CSD version 5.37; updated May 2017) for complexes of general formula $\left[\mathrm{RuCl}_{2}(\mathrm{CHPh})(\mathrm{L})_{2}\right](\mathrm{L}=$ phosphane or imidazol(in)-2-ylidene) gave 20 hits, 16 of them showing a trans arrangement of the L ligands. (b) See also, Groom, C. R.; Bruno, I. J.; Lightfoot, M. P.; Ward, S. C. Acta Cryst. 2016, B72, 171-179.

(10) See, for example: (a) Rouen, M.; Queval, P.; Falivene, L.; Allard, J.; Toupet, L.; Crévisy, C.; Caijo, F.; Baslé, O.; Cavallo, L.; Mauduit, M. Chem. Eur. J. 2014, 20, 13716-3721. (b) Sashuk, V.; Peeck, L. H.; Plenio, H. Chem. Eur. J. 2010, 16, 3983-3993. (c) Lane, D. R.; Beaver, 
C. M.; Olmstead, M. M.; Schore, N. E. Organometallics 2009, 28, 6789-6797. (d) Zhang, W.; Bai, C.; Lu, X.; He, R. J. Organomet. Chem. 2007, 692, 3563-3567. (e) Ledoux, N.; Allaert, B.; Linden, A.; Van Der Voort, P. Verpoort, F. Organometallics 2007, 26, 1052-1056. (f) Ritter, T.; Day, M. W.; Grubbs, R. H. J. Am. Chem. Soc. 2006, 128, 11768-11769. (g) Trnka, T. M.; Morgan, J. P.; Sanford, M. S.; Wilhelm, T. E.; Scholl, M.; Tae-Lim, C.; Ding, S.; Day, M. W.; Grubbs, R. H. J. Am. Chem. Soc. 2003, 125, 2546-2558. (h) Conrad, J. C.; Yap, G. P .A.; Fogg, D. E. Organometallics 2003, 22, 1986-1988. (i) Nieczypor, P.; van Leeuwen, P .W. N. M.; Mol, J. C.; Lutz, M.; Spek, A. L. J. Organomet. Chem. 2001, 625, 58-66. (j) Lynn, D. M.; Mohr, B.; Grubbs, R. H.; Henling, L. M.; Day, M. W. J. Am. Chem. Soc. 2000, 122, 6601-6609. (k) Weskamp, T.; Schattenmann, W. C.; Spiegler, M.; Herrmann, W. A. Angew. Chem. Int. Ed. 1998, 37, 2490-2493.

(11) (a) Álvarez-Rodríguez, L.; Cabeza, J. A.; Fernández-Colinas, J. M.; García-Álvarez, P.; Polo, D. Organometallics 2016, 35, 2516-2523. (b) Smart, K. A.; Mothes-Martin, E.; Vendier, L.; Perutz, R. N.; Grellier, M.; Sabo-Etienne, S. Organometallics 2015, 34, 4158-4163. (c) ÁlvarezRodríguez, L.; Cabeza, J. A.; García-Álvarez, P.; Pérez-Carreño, E.; Polo, D. Inorg. Chem. 2015, 54, 2983-2994. (d) Lipke, M. C.; Neumeyer, F.; Tilley, T. D. J. Am. Chem. Soc. 2014, 136, 6092-6102. (e) García, J. M.; Ocando-Mavárez, E.; Kato, T.; Santiago-Coll, D.; Briceno, A.; Saffon-Merceron, N.; Baceiredo, A. Inorg. Chem. 2012, 51, 8187-8193. (f) Fasulo, M. E.; Tilley, T. D. Chem. Commun. 2012, 48, 7690-7692. (g) Cabeza, J. A.; García-Álvarez, P.; Polo, D. Inorg. Chem. 2011, 50, 6195-6199. (h) Hayes, P. G.; Waterman, R.; Glaser, P. B.; Tilley, T. D. Organometallics 2009, 28, 5082-5089. (i) Takaoka, A.; Mendiratta, A.; Peters, J. C. Organometallics 2009, 28, 3744-3753.

(12) See, for example: (a) Prühs, S.; Lehmann, C. W.; Fürstner, A. Organometallics 2004, 23, 280-287. (b) Love, J. A.; Sanford, M. S.; Day, M. W.; Grubbs, R. H. J. Am. Chem. Soc. 2003, 125, 10103-10109. (c) Jafarpour, L.; Stevens, E. D. Nolan, S. P. J. Organomet. Chem. 2000, 606, 49-54. (d) Scholl, M.; Ding, S.; Lee, C. W.; Grubbs, R. H. Org. Lett. 1999, 1, 953-956. (e) Huang, J.; Stevens, E. D.; Nolan, S. P.; Petersen, J. L. J. Am. Chem. Soc. 1999, 121, 2674-2678. (f) Huang, J.; Schanz, H.-J.; Stevens, E. D.; Nolan, S. P. Organometallics 1999, 18, 5375-5380.

(13) See, for example: (a) Larocque, T. G.; Lavoie, G. G. New J. Chem. 2014, 38, 499-502. (b) Gatard, S.; Nlate, S.; Cloutet, E.; Bravic, G.; Blais, J.-C.; Astruc, D. Angew. Chem. Int. Ed. 2003, 
42, 452-456. (c) Volland, M. A. O.; Straub, B. F.; Gruber, I.; Rominger, F.; Hofmann, P. J. Organomet. Chem. 2001, 617, 288-291. (d) Werner, H.; Jung, S.; González-Herrero, P.; Ilg, K.; Wolf, J. Eur. J. Inorg. Chem. 2001, 1957-1961.

(14) See, for example: (a) DeHope, A.; Donnadieu, B.; Bertrand, G. J. Organomet. Chem. 2011, 696, 2899-2903. (b) Diesendruck, C. S.; Tzur, E.; Ben-Asuly, A.; Goldberg, I.; Straub, B. F.; Lemcoff, N. G. Inorg. Chem. 2009, 48, 10819-10825. (c) Salem, H.; Schmitt, M.; Herrlich, U. (née Blumbach); Kühnel, E.; Brill, M.; Nägele, P.; Bogado, A. L.; Rominger, F.; Hofmann, P. Organometallics 2003, 32, 29-49.

(15) A Karplus-type relationship between the $\mathrm{P}-\mathrm{Ru}-\mathrm{C}-\mathrm{H}_{\text {carbene }}$ dihedral angle and the observed $J_{\mathrm{PH}}$ coupling constant has been reported for Grubbs-type complexes. See, for example: Dias, E. L.; Nguyen, S. T.; Grubbs, R. H. J. Am. Chem. Soc. 1997, 119, 3887-3897.

(16) Trnka, T. M. Dias, E. L.; Day, M. W.; Grubbs, R. H. Arkivoc 2003, 28-41.

(17) Vougioukalakis, G. C.; Grubbs, R. H. J. Am. Chem. Soc. 2008, 130, 2234-2245.

(18) (a) Bantreil, X.; Poater, A.; Urbina-Blanco, C. A.; Bidal, Y. D.; Falivene, L.; Randall, R. A. M.; Cavallo, L.; Slawin, A. M. Z.; Cazin, C. S. J. Organometallics 2012, 31, 7415-7426. (b) Bantreil, X.; Schmid, T. E.; Randall, R. A. M.; Slawin, A. M. Z.; Cazin, C. S. J. Chem. Commun. 2010, 46, 7115-7117.

(19) (a) Tzur, E.; Szadkowska, A.; Ben-Asuly, A.; Makal, A.; Goldberg, I.; Wozniak, K.; Grela, K.; Lemcoff, N. G. Chem. Eur. J. 2010, 16, 8726-8737. (b) Barbasiewicz, M.; Szadkowska, A.; Bujok, R.; Grela, K. Organometallics 2006, 25, 3599-3604. (c) Ung, T.; Hejl, A.; Grubbs, R. H.; Schrodi, Y. Organometallics 2004, 23, 5399-5401. (d) Barbasiewicz, M.; Bieniek, M.; Michrowska, A.; Szadkowska, A.; Makal, A.; Wozniak, K.; Grela, K. Adv. Synth. Catal. 2007, 349, 193-203.

(20) Wiberg, K. B. Tetrahedron 1968, 24, 1083-1096.

(21) Energy associated with the release of the neutral ligand from the complex in the gas phase.

(22) Ritter, T.; Hejl, A.; Wenzel, A. G.; Funk, T. W.; Grubbs. R. H, Organometallics 2006, 25, $5740-5745$. 
(23) Nagendran, S.; Sen, S. S.; Roesky, H. W.; Koley, D.; Brubmüller, H.; Pal, A.; Herbst-Irmer, R. Organometallics 2008, 27, 5459-5463.

(24) CrysAlisPro RED, version 1.171.38.46; Oxford Diffraction Ltd.: Oxford, U.K., 2015.

(25) SIR-97: Altomare, A.; Burla, M. C.; Camalli, M.; Cascarano, G.; Giacovazzo, C.; Guagliardi, A.; Moliterni, A. G. C.; Polidori, G.; Spagna, R. J. Appl. Crystallogr. 1999, 32, 115119.

(26) SHELXL-2014: Sheldrick, G. M. Acta Crystallogr., Sect. A: Found. Crystallogr. 2008, 64, $112-122$.

(27) WINGX, version 2013.3: Farrugia, L. J. J. Appl. Crystallogr. 2012, 45, 849-854.

(28) MERCURY, CSD 3.9 (build RC1); Cambridge Crystallographic Data Centre: Cambridge, U.K., 2016.

(29) Chai, J.-D.; Head-Gordon, M. Phys. Chem. Chem. Phys. 2008, 10, 6615-6620.

(30) (a) Ehrlich, S.; Moellmann, J.; Grimme, S. Acc. Chem. Res. 2013, 46, 916-926. (b) Grimme, S. Comp. Mol. Sci. 2011, 1, 211-218. (c) Schwabe, T.; Grimme, S. Acc. Chem. Res. 2008, 41, 569-579.

(31) Minenkov, Y.; Singstad, Å.; Occhipinti, G.; Jensen, V. R. Dalton Trans. 2012, 41, 55265541.

(32) Metz, B.; Stoll, H.; Dolg, M. J. Chem. Phys. 2000, 113, 2563-2569.

(33) Dunning, T. H. J. Chem. Phys. 1989, 90, 1007-1023.

(34) Frisch, M. J.; et al. Gaussian 09, Revision A.01; Gaussian, Inc.: Wallingford, CT, 2009. 
Figure for the Abstract and Table of Contents

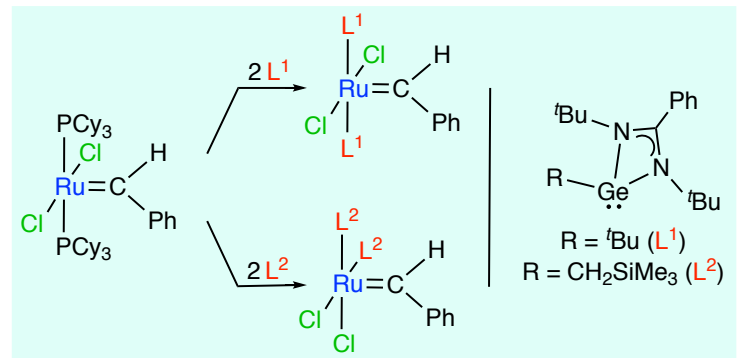

